\title{
ACCUMULATION OF ASSETS ON FARMS IN POLAND IN VIEW OF THE PRODUCTION TYPES AND THE CONTEXT OF THE SUSTAINABLE DEVELOPMENT PARADIGM
}

\author{
ALEKSANDER GRZELAK
}

\begin{abstract}
The main aim of the article is to recognize the accumulation of assets on farms in Poland due to the main type of farming. In addition, the paper takes into account the context of the sustainable farm paradigm. This was done in relation to the economic and environmental order of farms. The analysis based on the data of farms covered by the FADN system for 2004-2016. There is a wide range of differentiation between types of farms in terms of accumulation and its rate. The most favourable situation in this respect was on farms specialized in milk production and "granivores" (it is mainly about poultry farms). The level of accumulation (per $1 \mathrm{ha}$ ) and its rate increased with the growth in the economic size of farms in selected production types. Higher accumulation is accompanied by an increase in economic sustainability of the surveyed groups of farms. On the other hand, in the case of environmental sustainability, the relationships were reversed. This means that higher accumulation was accompanied by stronger pressure on the environment. It can be stated that the accumulation of fixed assets, as well as the relationships between accumulation and income (from the perspective of the accumulation rate) on farms only partially (in the economic order), favour development in the paradigm of sustainable development. Therefore, further valorisation of public goods through the EU CAP instruments in the next budget perspective (2020-2027) is important, as well as better adjustment of support to the scale of production.
\end{abstract}

Keywords: accumulation of assets, farm, sustainable development, type of farming.

JEL codes: Q12, Q50, D25.

Dr hab. Aleksander Grzelak, prof. nadzw. EUP, Uniwersytet Ekonomiczny w Poznaniu, Wydział Ekonomii; al. Niepodległości 10, 61-875 Poznań (agrzelak@interia.pl). ORCID iD: 0000-0002-4290-4740. 


\section{Introduction}

Farms operate and develop because of the continuity of production processes. This is accompanied by the accumulation of equity (assets), most often understood as the deposition of generated income. The accumulation of assets takes place either through investment or as a result of increase in land prices. The case concerns capitalization of subsidies or speculation. The most common channel for increasing own assets, within investment activities, are agricultural incomes. They create savings which form the basis for the expansion of farms. Since farmers' income is one of the assets accumulation channels a question may arise: whether there is any contradiction between the allocation of obtained income to consumption and accumulation? Assuming that satisfying the consumer's needs of a farmer's holding is paramount, only what is left over consumption can be used for investments and next it accumulates in the resources. Thus, in the short-term, these two processes: consumption and accumulation are competitive with each other. However, in the long term, these goals become more complementary. It results from the fact that the dynamics of accumulation processes determines in the future the size of resources, their efficiency, incomes, which influences meeting consumption needs.

The processes of accumulation of capital in agriculture are a function of both the past and the present. As a consequence, it is very difficult for smaller farms with lower assets to catch up with units stronger economically (Barham, Takasaki and Coomes, 2000). In turn, in the context of experience in Poland what draws attention is the importance of the business outlook for shaping the farmers' ability to invest and the rate of accumulation. The favourable economic situation favours accumulation (Woś, 2000).

In the literature, studies on the accumulation of assets often relate to the capitalization of agricultural support. As shown by the research results (Swinnen and Vranken, 2009; Góral and Kulawik, 2015) the direct payments under the CAP are capitalized in the rates of land lease, price of land and other fixed assets. In this way, accumulation is considered as the effect of direct payments support. This channel of accumulation is not desirable in agriculture. This is due to the increase in land prices and difficulties in the transformation of agrarian structures.

The growing interest in sustainable development in agriculture (Pretty, 2008; Gold, 2009; Woś and Zegar, 2002) caused that various aspects of farm operation are related to this paradigm. Starting from the processes of assets reproduction (Grzelak, 2016), through production resources (Smędzik-Ambroży, 2018) or the study of farms' eco-efficiency ${ }^{1}$ (Van Passel, Nevens, Mathijs and Van Huylenbroeck, 2009, Gadanakis, Bennett, Park and Areal, 2015). It results from the willingness of a multidimensional evaluation of economic processes, including the valorisation of public goods, external effects or the efficiency of environmental outlays.

\footnotetext{
${ }^{1}$ The term "eco-efficiency" appeared in the 1990s as a practical tool for measuring sustainable development. This is the relationship between the value of production and environmental inputs (e.g. consumption of fertilizers, energy, livestock density (Schaltegger and Sturm, 1990).
} 
The relationship between accumulation and the scale of production, or the economic size, is relatively obvious. A higher scale of production is accompanied by higher accumulation. Hence, it can be expected that farms with milk specialization will reach a high level, while the mixed farms will definitely be at a lower level. If we additionally take into account the environmental variable (pressure on the environment), we can expect that higher accumulation is associated with greater environmental pressure (Fig. 1). Farms with a similar production scale achieve a different level of accumulation due to its direction of production, the efficiency of the used resources, creating adequate isoquants (q1, q2, q3). With the transition to higher isoquants (as a consequence of an increase in the scale of production and the same economic size), environmental pressure increases. Simultaneously, at the same level of environmental pressure (in the absolute sense), one can expect that farms with a larger production scale can achieve a higher accumulation. It is due to the fact that larger units generally achieve a higher eco-efficiency of production (Van Passel et al., 2006). This is related to the fact that the larger UAA allows optimizing the environmental outlays, ensuring their more favourable transformation into production effects. This is especially in the case of land-intensive production (field crops). Therefore, for larger area farms, exceeding the hypothetical limit of environmental degradation takes place under conditions of higher accumulation (Fig. 1). It should be noted, however, that relatively high eco-efficiency may take place in conditions of environmental degradation and thus contradict the sustainable paradigm (Ehrmann, 2008).

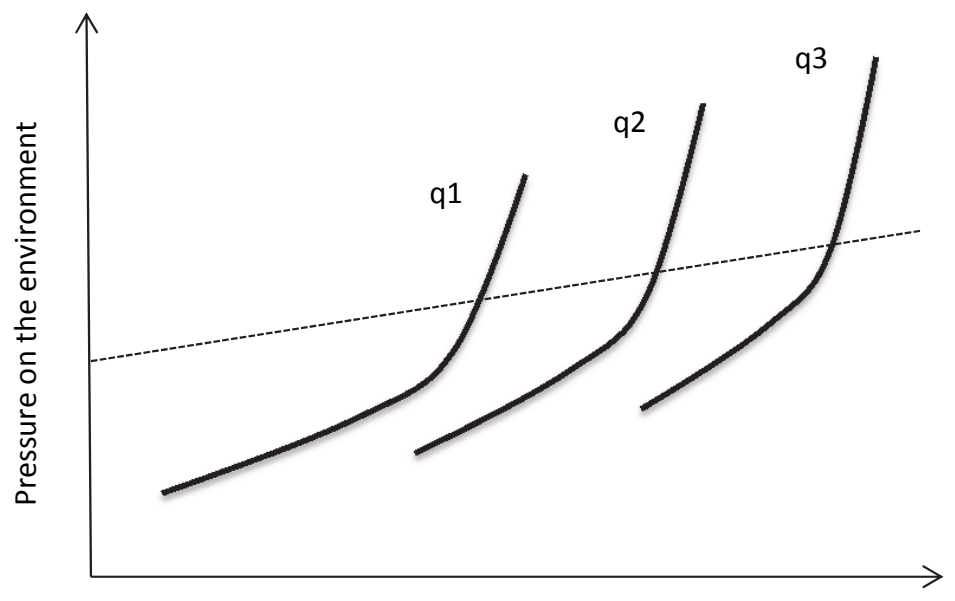

Accumulation of capital

q1, q2, q3 - farms accordingly, with a small, medium and large production scale

-------- - hypothetical limit of environmental degradation

Fig. 1. Theoretical relations between the accumulation of capital on farms and environmental pressure depending on the scale of production.

Source: own study. 
The main aim of the article is to recognize the accumulation of assets on farms in Poland due to the main type of farming, according to the FADN system (TF8). In addition, the context of the sustainable development paradigm of farms was taken into account. This was done in relation to the economic and environmental dimension of farms. The idea behind sustainable development paradigm, is that the farms by executing an economic goal, i.e. maximizing income that ensures their decent level (at least parity levels), at the same time, follow the principles of rational management of natural resources (Woś and Zegar, 2002). The economic dimension of sustainability is related to the achievement of parity income by the full-time employees on a farm who are family members of the farmer and the farmer him/ herself. This situation allows the allocation of surplus income for investments and accumulation of assets on farm.

Whereas the environmental dimension in the context of the sustainable paradigm is associated with measures referring to the pressure exerted by the farm on the environment, as well as the share of the subsidies related to payments for public goods. The context of environmental sustainability can also be reduced to agricultural practices limiting the pressure of farms on the environment. This is facilitated by the current CAP instruments in the form of cross-compliance, a component of greening under direct payments, agri-environmental programmes, subsidies to the LFA or the creation of a Natura 2000 site. The instruments of the CAP thus facilitate the integration of the economic and environmental objectives at the farm level. Of course, full integration of these objectives is possible only under specific conditions, e.g. within the framework of agricultural producers using ecological production systems. Nevertheless, it is important from the macroeconomic point of view, and thus from the macroeconomic perspective, to approximate these goals. The problem is whether the development of the farm from the perspective of asset accumulation and its rate (accumulation/income) increases the pressure on the environment?

The following research questions were formulated for the needs of the study:

- What are the differences regarding the accumulation in the group of surveyed farms between examined types of farming?

- Is higher accumulation accompanied by more or less sustainability or environmental pressure?

\section{Research methodology}

The data of farms conducting agricultural accounting in accordance with the principles of the FADN system (Wyniki..., 2017) were used in the article. The advantage of these data is diversity, detail and the possibility of using it for dynamic comparisons. In the field of observation of this system there are commercial farms, i.e. the main beneficiaries of the Common Agricultural Policy, which produce in a given region or country at least $90 \%$ of the standard value of production. Is a random selection of farms, taking into account the representativeness in terms of economic strength, their types and countries of origin. Despite the fact that the results of the agricultural accounting system cover only a part 
of farms (economically stronger), they are reliable for commercial farms in Poland, especially in the case of determining the trends of the studied phenomena. The analysed results referring to the average farm covered by the FADN system, whose situation is a result of the behaviour of many agricultural producers, gains systematic features and, at the same time, limits the randomness. Thus, the aggregation of data concerns thousands of farms, but the result is referred to the average farm in the surveyed group. The time scope of analyses refers to the years between 2004 and $2016^{2}$.

The accumulation of assets was considered through the prism of the change in the value of equity of farms (SE506). Thus, it contains changes in not burdened (liabilities) values of assets of a farm. In order to obtain more comprehensive assessments of accumulation, an indicator of the accumulation rate (accumulation/ income) was used to assess the relationship between agricultural income and accumulation in the context of the creation of accumulation from income. Due to the fact that there was no situation in the surveyed groups of farms in individual years when both: the nominator (accumulation) and the denominator (income) were simultaneously negative, this indicator did not create interpretation problems. The analysis was made taking into account the type of farming (TF8) selecting for evaluation of the most common types in Poland: field crops, dairy cows, grazing livestock, farms specialized in granivores (pigs, poultry) and farms with mixed production. In addition, due to the greater homogeneity of comparisons, additional comparisons were made which took into account the economic size class (ES6) ${ }^{3}$ within the given production types. Four classes are taken into account, which are the most important from the point of view of farm contacts with the market and their universality, i.e. ES2-ES5. In addition, on farms belonging to ES1 (economic size), agricultural income is relatively insignificant in the incomes of farm households, they produce to a limited extent for market needs, while the number of the largest farms, i.e. belonging to the ES6 class, is small (about 2000 units).

In the case of the context of sustainable paradigm the references to economic and environmental order were accepted. The first of these is about getting parity income. Thus, the agricultural incomes per 1 full-time employee of the member of the agricultural family were compared to the average net income in the economy using parity rates. The farms are more economically sustainable if their income reaches at least parity level (Wrzaszcz, 2012).

When it comes to the environmental aspects, assessment will use four factors separately: the indicator of material pressure on the environment, the share of payments for public goods in total subsidies, the indicator of production intensity

\footnotetext{
${ }^{2}$ It should be noted that due to the change (albeit to a small extent) of the typology of farms under the FADN, data from the period between 2004 and 2009 can be comparable with the data from 2010-2016 with caution in the case of farms with the separate type of farming.

${ }^{3}$ The economic size expressed in the value of standard output (in EUR thousand). Based on this parameter, delimitation is carried out into six size groups of farms: ES1- very small 2-8; ES2 - small 8-25; ES3 - medium-small 25-50; ES4 - medium-large - 50-100, ES 5 - large 100-500; ES6 - very large > 500.
} 
(animal density) and the share of forests in the total area. The first of the abovementioned, i.e. the indicators of material pressures on the environment makes it possible to compare the impact on the environment of farms using different means and production technologies. It was calculated as the sum of costs related to the purchase of fertilizers, plant protection chemicals, animal feed, energy per 1 ha of UAA (Piekut and Machnacki, 2011). Its higher values indicate higher environmental pressure from the perspective of material inputs.

In the case of payments for public goods, we can distinguish agri-environmental payments, set-aside payments, subsidies to less-favoured areas (LFA) and other payments for the rural development (Czyżewski, 2017). The higher share of these payments in total subsidies may indicate a more pro-environmental nature of support and thus the direction of development.

Significant for the evaluation of the environmental impact of farms and especially restrictions for animal production is livestock density per UAA (LU/1ha) (Majewski, 2002). This indicator together with the indicator of material pressure on the environment can determine approximately the pressure of farms on the environment. Exceeding certain values of the density of animals in relation to the used land areas informs about the high environmental intensity of the farm operation ${ }^{4}$. The aim is not to exceed the capacity for absorption of animal excrements by the agrosystem (Faber, 2001). On the other hand, it should be noted that organic fertilizers of animal production are valuable means of improving soil fertility. Therefore, in the case of a very low stocking density/ 1 ha, there may be problems with ensuring adequate soil fertility. In the case of other measures used with reference to the environmental order, no limit values were determined which provide a limit for sustainability of the farm. That is why the paper uses the median or mean of these indicators for the entire population of farms covered by the FADN system as a benchmark, along with a descriptive interpretation referring to the environmental dimension of sustainability. Finally, the share of forests in the total area determines the nature of the organization of production on farms, as well as the capacity for absorption of carbon dioxide, biodiversity or the so-called small retention.

Due to the great importance of land price changes in shaping accumulation, relevant estimates of this element of accumulation were made using changes in land prices per 1 ha of own land. The values of the tested parameters are presented in PLN after they have been realignment.

\footnotetext{
${ }^{4}$ The most often assumed level is $2 \mathrm{LU} / \mathrm{ha}$. This level results from the equivalent of a legally permissible natural manure dose of 170 kilograms of nitrogen. It should be noted, however, that in the Polish literature you can find numbers from 1.5 SD/ha (Majewski, 2002) and most often 2 LU/1 ha (Kopiński and Madej, 2006). These differences are mainly related to the conversion of physical animals into the so-called livestock unit. The relation of livestock to the area of UAA informs about the maximum load of natural fertilizers of the natural environment and allows for an ecological assessment of the organization on farms.
} 


\section{Research results}

Significant differences were noted in the accumulation between the years covered by the analysis (2004-2016), as well as the production types of farms in the group of surveyed farms, (Tables 1 and 2). Relatively high instability of accumulation per 1 ha resulted from changing conditions of the agricultural situation. Only in 2005 and partly in 2014, 2015 and 2016 we recorded a negative accumulation. The period between 2008 and 2009 may be surprising, when we were dealing with the global economic crisis in the economy. Meanwhile, the accumulation was positive in all tested types of farms production. This may have resulted from the inertia of previously initiated investment activities which with a delay accumulate in resources. The highest level of accumulation per 1 ha of UAA took place in the group of farms specializing in granivores ${ }^{5}$ (pigs and poultry), and milk production. In turn, the lowest level on farms specializing in grazing livestock (cattle) and without specialization. This was due to the scale of production, production profitability conditions (poultry) and the willingness to invest.

The last element is visible from the perspective of the accumulation rate (Table 2). Data analysis (Table 2) shows that especially on farms specializing in field crops and milk production, the accumulation rate in the analysed period was high. This means that a relatively high share of income was accumulated through investments in the development of farms. This is also confirmed by the results of Zawadzka, Strzelecka and Szafraniec-Siluta (2014) conducted on a group of farms in the field of FADN observation. They show that farms specializing in field crops had the highest self-financing capacity. Attention is drawn to the fact that the highest variability of the accumulation rate was recorded for farms without specialization (coefficient of variation at $210 \%$ ). Thus, paradoxically, the diversification of production did not serve to stabilize development processes through the prism of increasing assets (accumulation). However, this would require further research.

\footnotetext{
${ }^{5}$ This group of farms includes both farms with pig and poultry specialization. At the level of publicly available data, it is not possible to separate them from 2004 for farms being in the field of observation of the FADN system (about 730 thousand farms). Such classifications have been available since 2013, as well as for farms from the sample conducting agricultural accounting (12.3 thousand), so without the so-called data weighing. As a consequence, it makes the analysis of farms with the specialization of granivores difficult. While poultry farms have adapted to market conditions as well as export expansion as a consequence of integration with the EU, pig farms were characterized by worse economic results also as a consequence of ASF (Augustyńska, 2018). For example, in the group of farms conducting agricultural accounting (12.3 thousand) (i.e. better than those in the FADN observation field, which are weighted), the average accumulation per 1 ha of UAA was in 2016 for poultry holdings: PLN 2283 and PLN 877 for pigs. The income per 1 hour of own work was about 2.8 times higher on poultry farms than on pig farms.
} 
Table 1

Accumulation level ${ }^{a}$ per 1 ha of UAA on farms covered by the FADN system in Poland in 2004-2016 based on the selected type of farming TF8

\begin{tabular}{lrrrrr}
\hline \multirow{2}{*}{ Years } & \multicolumn{5}{c}{ Type of farming ${ }^{\mathrm{b}}$} \\
\cline { 2 - 6 } 2004 & \multicolumn{1}{c}{5} & \multicolumn{1}{c}{6} & 7 & \multicolumn{1}{c}{8} \\
\hline 2005 & -572.51 & 74.07 & -253.59 & -538.32 & -617.62 \\
2006 & 466.45 & $1,083.01$ & 661.31 & 646.99 & 473.30 \\
2007 & $1,151.62$ & $1,560.71$ & 983.50 & $1,181.94$ & $1,060.53$ \\
2008 & 610.29 & 670.76 & 90.81 & 482.95 & 152.89 \\
2009 & 585.81 & 341.04 & 339.84 & $1,364.64$ & 362.04 \\
2010 & 348.93 & 651.57 & 63.75 & 827.07 & 273.45 \\
2011 & 557.37 & $1,320.47$ & 280.40 & $1,351.05$ & 619.87 \\
2012 & 518.51 & 809.80 & 101.20 & 850.02 & 253.79 \\
2013 & 227.50 & 678.23 & 127.09 & 482.95 & 100.91 \\
2014 & 269.10 & 397.72 & 43.97 & 156.66 & -75.52 \\
2015 & 58.74 & -673.48 & -395.88 & -293.60 & -300.33 \\
2016 & -130.88 & 276.95 & 59.14 & 423.78 & -72.35 \\
\hline Mean & 356.30 & 626.04 & 185.07 & 609.06 & 362.86 \\
\hline
\end{tabular}

${ }^{a}$ SE 506 change in net worth of equity

${ }^{\mathrm{b}}$ Type of farming: 1 - field crops; 5 - milk; 6 - grazing livestock; 7 - granivores; 8 -mixed.

Source: own elaboration based on the FADN data contained on the website: http://europa.eu.int/comm/agriculture/rica/dwh/.

One of the components of accumulation is the change in the value of land prices over the level of inflation ${ }^{6}$. It turns out that farms specializing in field crops have benefited from this process the most (Table 3). It resulted from the largest average area of agricultural land occurring in this group of farms. In turn, it concerned to the smallest extent farms specializing in granivores. All in all, only on farms specializing in milk production and granivores without this component, the total accumulation would be positive. The question is how much did it result from the capitalization of payments? It can be assumed that in part it was also related to the effects resulting from restrictions on trade in agricultural land (relative stiffness of supply) in terms of high interest from the demand side (in many regions of Poland) and the relatively low popularity of land leases. As a consequence of a continuous, dynamic increase in the prices of agricultural land in Poland, the rate of capitalization of rents, as Laskowska (2011) points out,

\footnotetext{
${ }^{6} \mathrm{In}$ this case, determined through the prism of prices of products purchased by farmers.
} 
is low. This is also confirmed by Sikorska's research (2018). At the same time, for example, in 2008, the share of single area payment in the price of land was on average at $2.8 \%$ on for all farms, and in 2015 it was only about $1.5 \%$. All in all, the most favourable situation in terms of accumulation took place in the case of farms specializing in granivores.

Table 2

The accumulation rate a on farms covered by the FADN system in Poland in 2004-2016 based on the selected type of farming TF8

\begin{tabular}{cccccc}
\hline \multirow{2}{*}{ Years } & \multicolumn{5}{c}{ Type of farming } \\
\cline { 2 - 6 } & 1 & 5 & 6 & 7 & 8 \\
\hline 2004 & 49.79 & 57.88 & 45.19 & 42.06 & 212.97 \\
2005 & -59.73 & 4.63 & -47.73 & -26.11 & -67.96 \\
2006 & 36.24 & 47.00 & 48.18 & 25.31 & 31.05 \\
2007 & 70.91 & 64.76 & 81.89 & 58.59 & 67.89 \\
2008 & 53.24 & 34.06 & 10.67 & 23.01 & 14.04 \\
2009 & 63.88 & 25.00 & 58.74 & 38.64 & 38.50 \\
2010 & 23.21 & 30.09 & 7.60 & 27.32 & 20.89 \\
2011 & 45.66 & 60.34 & 27.33 & 47.28 & 49.60 \\
2012 & 38.01 & 45.08 & 10.29 & 27.46 & 22.59 \\
2013 & 21.44 & 36.15 & 15.16 & 12.98 & 10.51 \\
2014 & 24.82 & 20.03 & 5.42 & 3.88 & -9.12 \\
2015 & 5.88 & -38.98 & -54.23 & -7.95 & -46.58 \\
2016 & -14.13 & 14.50 & 6.95 & 12.75 & -8.58 \\
\hline Median & 36.24 & 34.06 & 10.67 & 25.31 & 20.89 \\
\hline
\end{tabular}

${ }^{a}$ income (SE420)/accumulation (SE 506 = change in net worth of equity)

Source: own elaboration based on the FADN data contained on the website: http://europa.eu.int/comm/agriculture/rica/dwh/.

Despite the lack of delimitation at the TF8 or TF14 level as regards the division of this group into poultry and pig farming, due to the existing profitability conditions, mainly poultry farms showed high development dynamics (footnote No. 5). The least favourable situation in the area of accumulation occurred, however, on farms with mixed production and those specializing in grazing livestock. In the first case, this resulted from the low range of specialization of the used assets, which as a consequence, made difficult the mechanization of work and increase in productivity. In turn, in the second case, it is not easy to explain. It can be assumed that this was due to the relatively lower production scale (through the prism of the value of standard output as well as UAA) in this type of farms in the field of observation 
of the FADN system and perhaps relatively less advanced specialization processes ${ }^{7}$. The point is that farms distinguished in the FADN group as specializing in grazing livestock are mainly connected with cattle production, but also milk production. This does not invalidate the operation of farms with very high specialization in the production of beef cattle focused mainly on export sales.

Table 3

The level of accumulation, the profitability of fixed assets and capital intensity of production (mean for 2004-2016) in farms covered by the FADN system

based on the selected type of farming TF8

\begin{tabular}{cccccc}
\hline $\begin{array}{c}\text { Type of } \\
\text { farming }\end{array}$ & $\begin{array}{c}\text { Value of } \\
\text { accumulation }\end{array}$ & $\begin{array}{c}\text { Value of } \\
\text { accumulation resulting } \\
\text { from changes } \\
\text { in the value of land }\end{array}$ & $\begin{array}{c}\text { Value of } \\
\text { accumulation } \\
\text { excluding changes } \\
\text { in the value of land }\end{array}$ & $\begin{array}{c}\text { Profitability } \\
\text { of fixed } \\
\text { assets }\end{array}$ & $\begin{array}{c}\text { Capital } \\
\text { intensiveness } \\
\text { of production }\end{array}$ \\
\hline 1 & $10,810.19$ & $11,666.01$ & -855.82 & 6.87 & 5.75 \\
5 & $12,144.61$ & $8,891.83$ & $3,252.78$ & 7.24 & 5.83 \\
6 & $2,905.89$ & $5,749.43$ & $-2,843.54$ & 3.94 & 9.58 \\
7 & $14,063.86$ & $2,083.91$ & $11,979.95$ & 10.01 & 2.34 \\
8 & $5,236.27$ & $6,881.41$ & $-1,645.14$ & 4.94 & 5.87 \\
\hline Mean & $9,032.16$ & $7,054.52$ & $1,977.65$ & 6.6 & 5.87 \\
\hline
\end{tabular}

a income (SE420)/value of fixed assets (SE441); ${ }^{\mathrm{b}}$ value of fixed assets (SE441)/output value (SE131)

Source: own elaboration based on the FADN data contained on the website: http://europa.eu.int/comm/agriculture/rica/dwh/.

Similar trends as in the case of accumulation per capita and the accumulation rate were recorded in the case of profitability of fixed assets and capital intensity of production (Table 3 ). These processes determine the scope of savings (also through the achieved efficiency), which translates into accumulation (Bezat-Jarzębowska and Rembisz, 2018). In the case of capital-intensive production, however, it should be noted that except farms specializing in granivores and grazing livestock, which stood out respectively in plus and in minus, the level of capital intensity for other separate types of farms was relatively similar. This means that the scale of production had an important role in increasing assets.

In order to make a more detailed reference to the accumulation of farm assets, also from the perspective of the paradigm of sustainable development, the division of farms into production types was additionally made for selected economic size

\footnotetext{
${ }^{7}$ For example, in 2016, the value of output in this group of farms was PLN 52,000, while average UAA 17.7 ha, while for all farms in the FADN field of observation it was on average PLN 126 thousand and 19.5 ha. Simultaneously, for dairy farms, the share of milk production in the total output was $67 \%$, in the case of farms specializing in grazing livestock the share of the main production, i.e. the value of beef production in the total output was $51 \%$. Confirmation regarding the rather low profitability of beef (and pork) production, e.g. for 2013-2014, can be found in the study of the team of the IERiGŻ (Sytuacja dochodowa i opłacalność produkcji rolnej w rolnictwie polskim w 2014 roku na tle lat poprzednich 2014).
} 
classes (Table 4). It follows from them that with the transition to the next, larger size of economic classes, there is an increase in economic sustainability. On farms from the ES3 size, in all production types, on average (in all examined units) we had to deal with at least a parity income. Interestingly, on farms specializing in granivores in the ES2-ES4 classes, the level of this sustainability was the lowest, as well as the scale of accumulation. In comparison with the previous analysis, it can be concluded that farms with this specialization achieved an advantage only at a higher production scale. This is also due to the fact that in higher economic size classes of this type of production, the importance of poultry production in relation to pigs increases ${ }^{8}$. The highest level of income per 1 full-time employee being the farmer's family (and himself) was noted for farms specializing in field crops. This is due to the relatively less labour-intensive production direction.

In the case of environmental impact, farms from higher economic size classes were accompanied by stronger pressure on the environment and thus lower sustainability. The most favourable situation, when it comes to environmental sustainability, occurred in the case of farms specializing in the grazing livestock, while the least in the case of granivores and in field crops. It resulted from the intensity of production within particular types of production of farms. In the light of the above, it can be stated that the direction of production, as well as the scale of production, determine the intensity of the environmental impact, which also coincides with the results of other studies (Wrzaszcz, 2017). While for all examined farms the median of the indicator of material pressure on the environment was 1760 PLN/1 ha, from this perspective we could say in some simplification that farms with a specialization in the production of granivores are far from sustainability.

\footnotetext{
${ }^{8}$ For example, if on farms with the economic size class of ES3, being in the field of FADN observation, the relation between the production value of poultry and pigs was in 2016, 0.11: 1, on ES5 farms it was 2.1: 1 . This is due to the choice of farms for this group (granivores). In 2016, in the group of farms with the specialization of granivores classified as economic size ES2 there were 3.5 thousand of poultry farms and 9.1 thousand of pig farms, while in the economic class of ES5 there were 2.7 thousand of poultry farms, and 2.5 thousand of poultry farms.
} 
The indicators relating to the environmental and economic sustainability

Table 4 of farms covered by the FADN system against the background of accumulation based on the selected type of farming (TF8) and economic size (ES6) (mean for 2004-2016)



\begin{tabular}{|c|c|c|c|c|c|c|c|c|c|}
\hline \multicolumn{10}{|c|}{ ES2 } \\
\hline 1 & $1,077.99$ & 0.16 & 3.26 & 0.07 & 0.95 & 0.16 & 254.75 & $9,686.05$ & $1,322.66$ \\
\hline 5 & $1,386.85$ & 0.22 & 8.49 & 0.94 & 0.60 & 0.11 & 258.75 & $-1,541.92$ & $1,495.36$ \\
\hline 6 & 974.53 & 0.31 & 8.53 & 0.77 & 0.47 & 0.12 & 163.59 & $-3,375.17$ & 864.67 \\
\hline 7 & $3,870.78$ & 0.19 & 5.96 & 1.57 & 0.46 & -0.31 & -221.58 & $-6,351.59$ & $1,337.28$ \\
\hline 8 & $1,587.86$ & 0.20 & 6.25 & 0.71 & 0.48 & 0.33 & 508.23 & $-4,202.54$ & $1,105.06$ \\
\hline \multicolumn{10}{|c|}{ ES3 } \\
\hline 1 & $1,181.92$ & 0.13 & 1.51 & 0.07 & 1.93 & 0.31 & 475.60 & $43,832.22$ & $1,394.60$ \\
\hline 5 & $1,752.29$ & 0.17 & 5.63 & 1.13 & 1.35 & 0.31 & 700.10 & $26,841.20$ & $2,025.11$ \\
\hline 6 & $1,079.03$ & 0.25 & 5.00 & 0.87 & 1.07 & 0.41 & 477.73 & $16,604.49$ & $1,119.68$ \\
\hline 7 & $4,291.34$ & 0.16 & 5.37 & 1.99 & 1.02 & 0.10 & 280.56 & $13,586.94$ & $1,931.66$ \\
\hline 8 & $2,013.99$ & 0.15 & 3.45 & 0.92 & 1.10 & 0.24 & 391.65 & $17,510.08$ & $1,426.36$ \\
\hline \multicolumn{10}{|c|}{ ES4 } \\
\hline 1 & $1,233.26$ & 0.12 & 1.32 & 0.06 & 3.43 & 0.53 & 714.82 & $96,091.18$ & $1,305.84$ \\
\hline 5 & $2,153.56$ & 0.15 & 4.08 & 1.23 & 2.58 & 0.42 & $1,081.70$ & $79,880.43$ & $2,438.17$ \\
\hline 6 & $1,150.73$ & 0.25 & 1.89 & 0.91 & 2.27 & 0.53 & 777.03 & $66,046.82$ & $1,416.28$ \\
\hline 7 & $6,024.49$ & 0.15 & 4.26 & 2.51 & 1.90 & 0.26 & 663.18 & $45,065.37$ & $2,502.78$ \\
\hline 8 & $2,285.31$ & 0.14 & 2.14 & 0.97 & 2.02 & 0.35 & 615.42 & $53,837.02$ & $1,614.17$ \\
\hline \multicolumn{10}{|c|}{ ES5 } \\
\hline 1 & $1,287.04$ & 0.09 & 0.63 & 0.04 & 8.60 & 0.59 & 615.80 & $232,201.25$ & $1,059.10$ \\
\hline 5 & $2,454.96$ & 0.12 & 2.28 & 1.18 & 5.31 & 0.47 & $1,054.89$ & $192,959.21$ & $2,250.83$ \\
\hline 6 & 937.15 & 0.24 & 1.08 & 0.86 & 3.20 & 0.55 & 557.68 & $94,788.56$ & 937.48 \\
\hline 7 & $11,162.35$ & 0.13 & 2.83 & 4.0 & 4.77 & 0.31 & $1,166.04$ & $151,076.68$ & $3,937.53$ \\
\hline 8 & $2,463.37$ & 0.11 & 1.19 & 0.84 & 4.45 & 0.50 & 679.07 & $134,415.94$ & $1,339.50$ \\
\hline
\end{tabular}

${ }^{a}$ costs of purchasing fertilizers (SE295)+ crop protection (SE300)+ energy (SE345) + feed (SE310+SE320)/ area of UAA (SE025); ${ }^{\text {}}$ agri-environmental payments (SE621)+ set-aside subsidies (SE612) + LFA payments (SE622)+ rural development subsidies (SE623)/total subsidies (SE406+SE605); ' SE080/SE025; ${ }^{d}$ the ratio of income (SE420)/(number of unpaid labour hours (SE016) * average parity rate in the economy); e gricultural income (SE420) - payment of own work of the farmer's and his family estimated on the basis of costs of wage paid (SE370) on farm

Source: own elaboration based on the FADN data contained on the website: http://europa.eu.int/comm/agriculture/rica/dwh/ and Skarżyńska (2004-2017). 
The largest share of payments for public goods took place on smaller farms specializing in grazing livestock and dairy production. In comparison with their relatively low environmental pressure and a high share of forest, it can be stated that these farms are rewarded by the support of the CAP system adequately to their role in the environmental surroundings. On the other hand, farms with field crop specialization significantly differed from the average values ${ }^{9}$ (for total surveyed population) in terms of the share of payments for public goods in total subsidies, as well as the share of forest in the total area of the farm. This was related to the relatively narrow specialization of production (cereals) and thus the crop monoculture, which makes it difficult to achieve environmental sustainability in this group of farms. It can also be noted that on farms belonging to smaller economic size classes (especially ES2), biodiversity was greater (from the perspective of the share of forest). It concerned, in particular, farms with milk and grazing livestock specializations.

In the case of stock density it was noticed that, on the one hand, on farms specializing in granivores, the intensity of production threatened the environment (exceeding 2 LU/1 ha) in units ES4-5 (economic size). They violated the limitations resulting from the Nitrates Directive, which was mainly caused by large positive balance of fertilizer components (Harasim, 2010). In part, this phenomenon may be associated with difficulties in obtaining agricultural land through buy or lease (including pastures and meadows). On the other hand, on farms with the specialization of field crops, regardless of the economic size, the stocking density was very low. As a result of the liquidation of livestock production (non-livestock farms), there is a negative balance of fertilizer components and organic matter in them, which reduces soil fertility (Harasim, 2013). In the other groups of farms, the stocking density was within the ranges that would allow relatively correct fertilizer management. For these reasons, farms specializing in granivores and field crops deviate from environmental sustainability conditions.

On farms classified to the higher economic size classes, the level of accumulation per 1 ha of UAA was higher, the accumulation rate as well as the profit. This means that stronger accumulation is accompanied by economic sustainability. This can also be confirmed by Pearson correlation coefficient between accumulation (per $1 \mathrm{ha}$ ), accumulation rate and economic sustainability in the group of surveyed farms. They were statistically significant and amounted, respectively, to 0.58 and 0.64 . In the case of the environmental dimension of sustainability, despite the fact that the opposite relationship is noticeable (higher accumulation - lower environmental sustainability), Pearson correlation coefficients have reached rather low values (about 0.3 ) for the analysed measures. This may indicate the complex character of the discussed compounds and requires further research on a larger research group.

\footnotetext{
${ }^{9}$ Average values for the share of payments for public goods in the total subsidies was $17.6 \%$ and for the share of an area of afforestation in the total area of farm $-4.7 \%$.
} 


\section{Conclusions}

These considerations lead to the following conclusions:

- There is a significant range of differentiation between types of farms in terms of accumulation and its rate. The most favourable situation on farms specializing in milk production and granivores (mainly poultry farms). The least favourable, on farms with the specialization in grazing livestock and on mixed farms.

- The amount of accumulation (per $1 \mathrm{ha}$ ) and its rate, increased with the growth in the economic size of farms in the individual type of farming. This is due to the economies of scale and the wider possibilities of optimizing production resources. At the same time, it was noted that great importance for accumulation has the channel associated with the increase in the value of the land. This phenomenon adversely impacts especially on environmental sustainability, due to difficulties in the purchase of land.

- It was noticed that higher accumulation is accompanied by an increase in economic sustainability in the surveyed groups of farms. It is easier for larger farms to achieve parity income for their family members. On the other hand, in the case of environmental sustainability, the relationships were reversed: higher accumulation was accompanied by stronger pressure on the environment. However, this has not been reflected by relatively high correlation coefficients. It does not mean, however, that there is a lack of these dependencies in practice.

- The most favourable, in terms of low impact on the environment, were farms specializing in grazing livestock. They are paid to a greater extent by the support system (CAP) payments for public goods. In this way, their significance in the environmental surroundings is valorized

- Farms specializing in "granivores" achieve high accumulation (especially in greater economic size), but their negative impact on the environment is the strongest among the analysed types. It creates the need to apply appropriate agricultural practices limiting environmental pressure in this group of farms. The barrier here is also the restrictions (high prices, small number of offers) on the enlargement of the area of farms through the purchase or lease of land. What cannot be classified in environmental sustainability terms are farms with the specialization of field crops. On the whole they are without livestock, which negatively affects soil fertility and the level of biodiversity is low.

- It can be concluded that accumulation of assets, as well as relationships between accumulation and income (from the perspective of the accumulation rate) on farms only partially (i.e. in the economic order) favour development in the paradigm of sustainable development. The only exception may be farms specializing in milk production belonging to ES3 (economic size) in which there is sustainability both in the economic and environmental dimension. Therefore, it is important to further valorise public goods through the CAP instruments in the next budget perspective (2020-2027), as well as adjust support to the scale of production. Simultaneously, the acceleration of accumulation while limiting environmental pressure can be seen in the greater liberalization of trade in agricultural land. 


\section{Financing sources}

The paper was financed under the funds of the National Science Centre in Poland grant No. 2018/29/B/HS4/01844. 


\section{References}

Augustyńska, I. (2018). Opłacalność produkcji wybranych produktów rolniczych w Polsce w latach 2013-2017. Warszawa: IERiGŻ. Retrieved from: https://www.ierigz.waw.pl/.../22293-Oplacalnosc_produktow_Augustynska_pdf (access date: 20.05.2019).

Barham, B., Takasaki, Y., Coomes, O. (2000). Are endowments Fate? An Econometric Analysis of Multiple Asset Accumulation in a Biodiverse Environment. Conference Tokyo, Japan. Retrieved from: http://www.gdnet.org/pdf/890_Yoshito.pdf (access date: 10.05.2019).

Bezat-Jarzębowska, A., Rembisz, W. (2018). Mikroekonomia relacji czynników produkcji w rolnictwie. Ujęcie analityczne mechanizmów. Warszawa: Wydawnictwo Wyższej Szkoły Zarządzania i Finansów.

Czyżewski, B. (2017). Kierat rynkowy w europejskim rolnictwie. Warszawa: PWN.

Ehrmann, M. (2008). Comparing Sustainable Value Approach, Data Envelopment Analysis and indicator approaches - An application on German dairy farms. $12^{\text {th }}$ Congress of the European Association of Agricultural Economists - EAAE 2008. Ghent, Belgium. Retrieved from: http://purl.umn.edu/44140 (access date: 2.02.2019).

Faber, A. (2001). Wskaźniki proponowane do badań równowagi rozwoju rolnictwa. Fragmenta Agronomica, No. 1(69), pp. 1-44.

Gadanakis, Y., Bennett, R., Park, J., Areal, F. (2015). Evaluating the Sustainable Intensification of arable farms. Journal of Environemtnal Management, No. 150. Retrieved from: http:// centaur.reading.ac.uk/37916/1/Final_SI_Yiorgos_Gadanakis.pdf (access date: 15.03.2019).

Gold, M. (2009). What is Sustainable Agriculture? United States Department of Agriculture, Alternative Farming Systems Information Center.

Góral, J., Kulawik, J. (2015). Problem kapitalizacji subsydiów w rolnictwie. Zagadnienia Ekono-miki Rolnej, No. 1(342), pp. 3-32.

Grzelak, A. (2016). Evaluation of the reproduction processes in farms in Poland in context of the environmental and economic sustainability. International Journal of Economic Policy in Emerging Economies, Vol. 9, No. 2, pp. 169-181.

Harasim, A. (2010). Realizacja zasad zrównoważonego rozwoju w gospodarstwach rolniczych o różnych kierunkach produkcji. Studia i Raporty IUNG-PIB, No. 22, pp. 57-64.

Harasim, A. (2013). Agroekologiczna ocena zrównoważenia uspołecznionych gospodarstw rolnych. Roczniki Naukowe SERiA, Vol. 15, No. 2, pp. 101-105.

http://europa.eu.int/comm/agriculture/rica/dwh/.

Kopiński, J., Madej, A. (2006). Ilość azotu dostarczanego w nawozach naturalnych w zależności od obsady zwierząt. Nawozy i Nawożenie, No. 4, pp. 16.

Laskowska E., (2011). Inwestowanie na rynku gruntów rolnych w Polsce. Roczniki Nauk Rolniczych, seria G, t. 98, z. 3, s. 150-159.

Majchrzak, A. (2015). Ziemia rolnicza $w$ krajach Unii Europejskiej $w$ warunkach ewolucji Wspólnej Polityki Rolnej. Warszawa: PWN.

Majewski, E. (2002). Ekonomiczno-organizacyjne uwarunkowania rozwoju Systemu Integrowanej Produkcji Rolniczej (SIPR) w Polsce. Warszawa: SGGW.

Piekut, K., Machancki, M. (2011). Ocena ekologiczno-ekonomiczna gospodarstw rolnych na podstawie danych FADN. Woda-Środowisko-Obszary wiejskie, No. 1(33), Vol. 11, pp. 209.

Pretty, J. (2008). Agricultural sustainability: concepts, principles and evidence. Philosophical Transactions of the Royal Society of London B: Biological Sciences, 363(1491), pp. 447-465. Doi:10.1098/rstb.2007.2163. 
Rynek ziemi rolniczej. Stan i perspektywy (2018). Analizy Rykowe, No. 21. Warszawa: IERiGŻ-PIB, ARR, MRiRW.

Schaltegger, S., Sturm, A. (1990). Ökologische Rationalität: Ansatzpunkte zur Ausgestaltung von ökologieorientierten Managementinstrumenten. Die Unternehmung, No. 44(4), pp. 273-290.

Smędzik-Ambroży, K. (2018). Zasoby a zrównoważony rozwój rolnictwa w Polsce po akcesji do Unii Europejskiej. Warszawa: PWN.

Skarżyńska, A. (2005-2017), Produkcja, koszty i dochody uzyskane z produkcji wybranych produktów rolniczych $w$ latach 2004-2016. Warszawa: IERiGŻ-PIB.

Swinnen, J., Vranken, L. (2009). Land \& EU Accession. Review of the Transitional Restrictions by New Members States on the Acquisition of Agricultural Real Estate. Brussels: Centre for the European Policy Studies (CEPS).

Sytuacja dochodowa i opłacalność produkcji rolnej $w$ rolnictwie polskim $w 2014$ roku na tle lat poprzednich (2014). Warszawa: IERiGŻ. Retrieved from: http://www.kzp-ptch.pl/images/Publikacje/IERiGZ/Sytuacja_dochodowa_i_op\%C5\%82acalno\%C5\%9B\%C4\%87_ produkcji_w_Polsce.pdf (access date: 5.06.2019).

Van Passel, S., Nevens, F., Mathijs, E., Van Huylenbroeck, G. (2006). Explaining Differences in Farm Sustainability: Evidence from Flemish Dairy farms. International Association of Agricultural Economists Conference, Gold Coast, Australia, August 12-18. Retrieved from: https://ageconsearch.umn.edu/bitstream/25262/1/cp060302.pdf. (access date: 10.03.2019).

Woś, A. (2000). Inwestycje i akumulacja w rolnictwie chłopskim w latach 1988-1998. Warszawa: IERiGŻ.

Woś, A., Zegar, J.S. (2002). Rolnictwo społecznie zrównoważone. Warszawa: IERiGŻ.

Wrzaszcz, W. (2017). Wyniki produkcyjno-ekonomiczne gospodarstw rolnych oddziałujących w różnym zakresie na środowisko przyrodnicze. Zagadnienia Ekonomiki Rolnej, No. 2(352), pp. 3-31.

Wrzaszcz, W. (2012). Czynniki kształtujące poziom zrównoważenia gospodarstw rolnych. In: J. Zegar (ed.), Z badań nad rolnictwem społecznie zrównoważonym (15) (s. 79-10). Progam Wieloletni 2011-2014, No. 50. Warszawa: IERiGŻ-PIB.

Wyniki standardowe 2016 uzyskane przez gospodarstwa rolne uczestniczace w polskim FADN. Część I. Wyniki standardowe (2017). IERiGŻ-PIB, Warszawa.

Zawadzka, D., Strzelecka, A., Szafraniec-Siluta, E. (2014). Ukierunkowanie produkcji gospodarstwa rolnego a zdolność do samofinansowania nakładów inwestycyjnych - ujęcie porównawcze. Journal of Management and Finance, Vol. 12, No. 3, cz. 1, pp. 289-305. 


\title{
AKUMULACJA MAJĄTKU W GOSPODARSTWACH ROLNYCH W POLSCE ZE WZGLĘDU NA TYPY PRODUKCYJNE I KONTEKST PARADYGMATU ROZWOJU ZRÓWNOWAŻONEGO
}

\begin{abstract}
Głównym celem artykułu jest rozpoznanie procesów akumulacji majątku w gospodarstwach rolnych $w$ Polsce ze względu na główne typy produkcyjne. Ponadto uwzględniono kontekst paradygmatu zrównoważonego gospodarstw rolnych. Zrealizowano to $w$ odniesieniu do ładu ekonomicznego i środowiskowego gospodarstw. Analizy przeprowadzono na podstawie danych gospodarstw rolnych objętych systemem FADN dla lat 2004-2016. Istnieje znaczny zakres zróżnicowania pomiędzy typami gospodarstw rolnych jeśli chodzi o akumulację, jak i jej stope. Najkorzystniejsza sytuacja $w$ tym zakresie miała miejsce $w$ gospodarstwach rolnych specjalizujacych się $w$ produkcji mleka i chowie zwierząt ziarnożernych (chodzi tu głównie o gospodarstwa drobiowe). Wielkość akumulacji (na 1 ha) oraz jej stopa zwiększały się wraz ze wzrostem wielkości ekonomicznej gospodarstw rolnych w poszczególnych typach produkcyjnych. Większej akumulacji towarzyszy wzrost zrównoważenia ekonomicznego dla badanych grup gospodarstw rolnych. W przypadku natomiast zrównoważenia środowiskowego zależności układały się odwrotnie. Oznacza to, ̇̇e wyższej akumulacji towarzyszyła silniejsza presja na środowisko. Można stwierdzić, że procesy akumulacji majątku, jak i związków akumulacji i dochodów (z perspektywy stopy akumulacji) w gospodarstwach rolnych tylko częściowo (w tadzie ekonomicznym) sprzyjaja rozwojowi w paradygmacie rozwoju zrównoważonego. Dlatego ważna jest dalsza waloryzacja dóbr publicznych poprzez instrumenty WPR UE w kolejnej perspektywie budzetowej (2020-2027), jak i lepsze dostosowanie wsparcia do skali produkcji.
\end{abstract}

Słowa kluczowe: akumulacja majątku, gospodarstwo rolne, zrównoważony rozwój, typ produkcyjny.

Accepted for print: 13.09.2019.

Unless stated otherwise all the materials on the website are available under the Creative Commons Attribution 4.0 International license.

Some rights reserved to the Institute of Agricultural and Food Economics - National Research Institute.

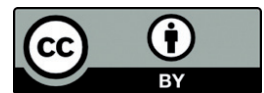

